\title{
LAND DEGRADATION TREND ASSESSMENT OVER IBERIA DURING 1982-2012
}

\author{
C.M. GOUVEIA*, P. PÁSCOA, \\ A. RUSSO, R.M. TRIGO
}

Instituto Dom Luís, Faculdade de Ciências da Universidade de Lisboa, Portugal.

\begin{abstract}
Land degradation is recognized as an important environmental and social problem in arid and semi-arid regions, particularly within a climate change context. In the last three decades the entire Mediterranean basin has been affected by more frequent droughts, covering large sectors and often lasting more than one year. The Iberian Peninsula has been equally affected by intense drought events since the 1980s. According to the latest IPCC report the Mediterranean region will suffer further hydrological stress in the coming decades, as a consequence of diminishing of precipitation and increasing of both average and extreme temperatures. This climatic outlook coupled with the land abandonment and/or intensification of some areas requires a continuous monitoring and early detection of degradation. The present work intends to contribute to such objectives.
\end{abstract}

Land degradation could be stated as a longstanding deterioration in ecosystems productivity. Here we assess the ability of NDVI to be used as an indicator of land degradation over Iberia, from 1982 to 2012. The negative trends of the residuals obtained after removing the precipitation influence on NDVI were assumed to indicate land degradation. A widespread land improvement was observed over Iberia with few hot spots of land degradation located mainly in central and southern sectors and in east Mediterranean and Atlantic coasts. The comparison of spatial patterns of residual trends with dryness for the aridity regions over Iberia highlighted the relatively small fraction of land degradation that experiences an increased dryness, although almost totality belonging to semi-arid region. On the other hand, land improvement is only associated with a tendency of wetness in the northeastern humid sector. Moreover, less than $20 \%$ of the area presenting land degradation corresponds to regions associated with land cover changes, being the new land cover types associated with transitional woodland-shrub, permanent and annual crops and permanently irrigated land areas. 


\section{Evaluación de la tendencia a la degradación del suelo en Iberia durante 1982-2012}

RESUMEN. La degradación del suelo es un problema ambiental y social en regiones áridas y semiáridas, particularmente en un contexto de cambio climático. En las tres últimas décadas toda la cuenca mediterránea se ha visto afectada por sequías más frecuentes, cubriendo amplios sectores y a menudo con una duración superior a un año. La Península Ibérica se ha visto igualmente afectada por intensos eventos de sequía desde la década de 1980. Según el último informe del IPCC, la Península Ibérica sufrirá más estrés hídrico en las próximas décadas como consecuencia del descenso de la precipitación y el incremento de las temperaturas medias así como de las temperturas extremas. Este escenario climático, junto con el abandono de tierras y/o intensificación de algunas áreas, requiere un monitoreo continuo y una detección temprana de la degradación. Este trabajo trata de contribuir a esos objetivos.

La degradación del suelo podría definirse como un deterioro a largo plazo en la productividad de los ecosistemas. Aquí establecemos la capacidad del NDVI como indicador de la degradación del suelo en Iberia desde 1982 a 2012. Las tendencias negativas de los residuales obtenidos eliminando la influencia de la precipitación en el NDVI se asumieron como indicadores de degradación del suelo. Una generalizada mejoría del suelo se observó en Iberia, con unos pocos puntos calientes de degradación, localizados principalmente en la zona central y meridional y en las costas mediterránea y atlántica. La comparación de los patrones espaciales de las tendencias de los residuales con sequía para las regiones áridas subraya la relativamente pequeña proporción de suelo degradado que sufre una creciente sequía, casi completamente perteneciente a la zona semiárida. Por otro lado, la mejoría del suelo se asocia sólo con la tendencia a la humedad en el sector húmedo del nordeste. Además, menos del $20 \%$ del área que presenta degradación del suelo corresponde a regiones asociadas con cambios de uso del suelo, estando los nuevos usos del suelo relacionados con matorrales, cultivos permanentes y anuales y áreas de regadio.

Key words: land degradation, NDVI, precipitation, Iberian Peninsula, RESTREND, SPEI-SPI.

Palabras clave: degradación del suelo, NDVI, precipitación, Península Ibérica, RESTREND, SPEI-SPI.

Received 1 February 2016

Accepted 18 March 2016

*Corresponding author: C. M. Gouveia, Instituto Dom Luís, Faculdade de Ciências da Universidade de Lisboa, Campo Grande. Edifício C8, Piso 3, 1749-016 Lisboa, Portugal. E-mail: cmgouveia@fc.ul.pt 


\section{Introduction}

Land degradation is recognized as a major environmental and social problem. The Millennium Ecosystem Assessment (Safriel and Adeel, 2005) describes land degradation as "the reduction in the capacity of the land to perform ecosystem goods, functions and services that support society and development". According to the United Nations Convention to Combat Desertification (UNCCD) the term desertification "means land degradation in arid, semi-arid and dry sub-humid areas resulting from various factors, including climatic variations and human activities" (UNCCD, 1994). Although in the past, drylands had the capacity to recover easily from severe and long drought events, presently human activities such as overgrazing and over cultivation are reducing the resilience of drylands ecosystems. Consequently it also labels desertification for the cases where land degradation occurs in arid and semi-arid environments. The monitoring and early detection of desertification land degradation processes are vital to avoid the irreversible decline of land conditions and the setup of desertification that can lead to ecosystems regime shifts (Bestelmeyer et al., 2015). However, the assessment of land degradation and desertification is a very complex process, starting with the definition of both concepts (Higginbottom and Symeonakis, 2014). We assume land degradation as a longstanding deterioration in ecosystems' productivity and the associated deterioration in potential plant productivity results from both human induced processes and climate factors. As human disturbances, land use changes and wildfires' occurrences assume a crucial role, whereas the main climate factors are the inter-annual variability of precipitation, sunshine and consequently the variations on growing season length (Bai et al., 2008).

Land degradation and desertification assessment is of crucial importance in the Mediterranean basin, a region with a very long tradition in land management (Reale and Dirmeyer, 2000), and also with a well-reported desertification tendency (de Wrachien et al., 2006). However in some Mediterranean regions positive trends in vegetation activity were found spread throughout almost everywhere (del Barrio et al., 2010). However, when the entire Mediterranean basin is considered, spots of negative trends were detected in degraded lands and positive trends in regions with land in good conditions. On the other hand, in the last three decades the entire Mediterranean basin has been affected by more frequent droughts, covering large sectors and often lasting more than one year. According to the latest IPCC report the Mediterranean region will suffer further hydrological stress in the coming decades, as a consequence of diminishing of precipitation and increasing of both average and extreme temperatures (IPCC, 2012). Located in western Mediterranean, the Iberian Peninsula has been equally affected by intense drought events since the 1980s (Garcia-Herrera et al., 2007; Vicente-Serrano et al., 2011; Gouveia et al., 2012). However, recent works show that the land throughout Iberia is in relatively good conditions, with isolated spots of land degradation that could be connected with land use changes, particularly the use of intensive agricultural techniques (del Barrio et al., 2010). Moreover Hill and co-authors (2008), using remote sensing information between 1989 and 2004, also identified over Iberia a widespread vegetation increase with local areas of land degradation. They attributed the decline in productivity to wildfires, namely to the large burned scars during the 2003 fire season 
in Portugal, whereas the land improvement is mainly attributed to the abandonment of rural areas (Hill et al., 2008). On the other hand, Arribas et al. (2003) analyzed how land degradation affects the climate in Mediterranean basin, identifying a strong decline of precipitation in northeastern Iberia, which is one of the less degraded areas of the Peninsula.

Remote sensing techniques assume an important role for the development of monitoring and early assessment of land degradation (Higginbottom and Symeonakis 2014). Land degradation is usually evaluated as a longstanding deterioration in ecosystem productivity, as assessed by changes in NPP, Net Primary Productivity (Phillips et al., 2008). However anomalies (departures from the mean values) of Normalized Difference Vegetation Index (NDVI) could also be used as a proxy for land degradation. NDVI has been widely used to estimate vegetation dynamics (Gouveia et al., 2008; Bastos et $a l ., 2016$ ), namely in the case of droughts and heatwave extreme events (Gouveia et al., 2009, 2012, 2016). Likewise NDVI can be used and as an input of dynamical models (Nemani et al., 2003) and for inter-model comparison purposes (Bastos et al., 2016). Several works have shown the relation of NDVI with biophysical parameters, such as (i) LAI, leaf-area index (Myneni et al., 1997), (ii) fAPAR, the fraction of photosynthetically active radiation absorbed by vegetation (Fensholt et al., 2004), and (iii) NPP (Phillips et al., 2008). However, some limitations exist on the use of NDVI, as it has restrictions in regions with sparse vegetation due to the soil contamination, and also because when NDVI is used as a proxy for vegetation productivity it does not provide any useful information about the type of degradation/improvement (Bai et al., 2008).

Nevertheless, NDVI is commonly used as an indicator of NPP, although NDVI revealed to be better for cropland and grassland than for forest (Bai et al., 2008). Thus, NDVI was used for assessing land degradation and desertification in the Sahel region of sub-Saharan Africa (e.g. Prince et al., 1998; Holm et al., 2003; Anyamba and Tucker, 2005; Fensholt et al., 2011). This region has experienced a decrease in precipitation between 1960 and 1990 (Higginbottom and Symeonakis, 2014) and was hit by several intense drought episodes in 1973, 1985 and 1990 (Hulme, 2001). However, in recent years, several studies using again NDVI revealed a recent greening trend (Eklundh and Olson, 2003; Herrmann et al., 2005; Fensholt et al., 2011; Huber et al., 2011). This greening trend was also found in other semi-arid regions that were pointed before as hotspots of land degradation (De Jong et al., 2011). The changes in NDVI trends are usually related with changes in precipitation variability (Hickler et al., 2005), namely in arid regions where vegetation is highly controlled by precipitation (Gouveia et al., 2008). Therefore a negative (positive) trend in NPP does mean inevitably land degradation (improvement). However, it is now widely accepted that prior to the NPP-land degradation assessment, the precipitation effect on vegetation should be removed.

Several approaches have been proposed to accommodate such role played by precipitation. The earliest method corresponds to the rain-use efficiency (RUE) concept originally proposed by Le Houérou (1984). RUE is defined as the ratio between annual NPP and precipitation and, for regions where vegetation productivity is limited by precipitation, this index reveals to be sensitive to rainfall variability and soils 
characteristics (Prince et al., 2007). However RUE presents some limitations in the case of land degradation assessment (Hein and Ridder, 2006). In regions characterized by high annual precipitation values, precipitation is not a limitation and other factors, namely temperature, among others, may play a more relevant role on the control of vegetation productivity (Gouveia et al., 2008; Bastos et al., 2014). Another problem can occur in regions characterized by low annual precipitation, where RUE values can tend to infinite. Additionally, RUE and precipitation cannot be regarded as independent variables (Dardel et al., 2014). Consequently and with the aim of avoiding the existence of correlations between NDVI and precipitation, Fensholt et al. (2013) suggested using the sum of NDVI for the rainy season and accounting only for the increase of NDVI relative to a determined threshold, instead of the integral of NDVI for the entire year. Other approaches use statistical methods to disentangle NDVI from precipitation, namely the Residual Trends (RESTREND) method (Archer, 2004; Evans and Geerken, 2004) and the Precipitation Marginal Response (PMR) (Verón and Paruelo, 2010) with satisfactory results. In the former method, a regression between NDVI and precipitation was computed and a trend analysis of the residuals from this regression and of the original NDVI was performed. The later method quantifies the slope of the linear regression between productivity as obtained by NDVI or NPP and precipitation.

The main objective of this work is to assess land degradation throughout the Iberian Peninsula using NDVI from the Global Inventory Modeling and Mapping Studies (GIMMS), spanning from 1982 to 2012. Following the RESTREND method mentioned above, the NDVI and Precipitation datasets were used with the aim of simulating a new NDVI (NDVIsim) obtained by linear regression with precipitation (using 0,1 and 2 lag years). A trend analysis was performed on the residual between NDVI and NDVIsim. The spatial patterns of residual trends over Iberia will be compared with the spatial patterns of the difference between two drought indices (the Standardized Precipitation and Precipitation-Evapotranspiration indices, respectively SPI and SPEI). The relationship between these patterns with climate variability and land use cover / change will also be analyzed.

\section{Data and methods}

\subsection{NDVI}

The NDVI from the GIMMS dataset is obtained using raw data acquired by the Advanced Very High Resolution Radiometer (AVHRR) sensor onboard the NOAA satellite series (7, 9, 11, 14, 16 and 18). The GIMMS NDVI dataset has been corrected and calibrated geometrically, as well as for volcanic aerosols, and other effects not related to vegetation change (Pinzon and Tucker, 2014). The GIMMS dataset has the spatial resolution of $8 \mathrm{~km}$ and is the longest remote sensing dataset covering the entire globe, being at the moment available from 1982 until 2012 (Tucker et al., 2005; Pinzon and Tucker, 2014). Taking in account the availability of more than 30 years of high quality data and its temporal consistency, this dataset has been widely used to analyze vegetation dynamic and climate impacts on vegetation (e.g., Buermann et al., 2003; Gouveia et al., 2008; Bastos et al., 2016). 
The monthly composites of GIMMS-NDVI were obtained through the application of the Maximum Value Composite method (Holben, 1986).

\subsection{Precipitation and Evapotranspiration}

The Climate Research Unit TS3.21 gridded database (Harris et al., 2014) with a grid point resolution of 0.5 degrees was used in this work. This dataset is based on monthly observations of several climate variables from more than 4000 weather stations spanned around the world. The database is checked for heterogeneities in data records using an automated method (Mitchell and Jones, 2005). A number of relevant variables for this work, including precipitation and temperature were extracted from January 1980 until December 2012. The reference evapotranspiration was estimated based on the Hargreaves method (Hargreaves and Samani, 1985). The time evolution of the accumulated annual precipitation averaged for the entire Peninsula was computed, as well as the trends of precipitation and their associated level of statistical significance for each grid point of the CRU dataset over the Iberian Peninsula for the available period.

In order to assess the impact of climatic conditions on land degradation, the Aridity Index (AI) was computed as the average of the ratio between annual total precipitation (P) and reference evapotranspiration (ET), for the Iberian Peninsula on the period 1982-2012, as shown on Equation 1. Results were grouped in 7 aridity classes (Spinoni et al., 2015).

$$
A I=\frac{\sum_{i=1}^{31}\left(\frac{P_{i}}{E T_{i}}\right)}{31}
$$

\subsection{Drought indices-SPEI and SPI}

Drought has been defined as a deficit of precipitation over a period of time in a specific location leading to various negative impacts, namely in water resources, agriculture and socio-economic activities, among others. The significant impact of large, intense or frequent drought events on land degradation has been stated for a long time (Nicholson et al., 1998). The higher spatial variability of precipitation, namely in Mediterranean regions, originates different drought concepts and assessment for this climate event. In order to monitor and evaluate this complex phenomenon in recent years a large number of drought indicators have been developed with the aim of monitoring droughts, as well as at assessing their impacts in several sectors ranging from environmental to social. From the available tools normally used to identify drought events, the multi-scalar drought indices have the advantage of being very adaptable to different systems and assisting the analysis of drought impacts on several ecological systems that may respond to drought at different time-scales. The Standardized Precipitation Index is the most widely used, although being based only on precipitation data (McKee et al., 1993). In simple terms, SPI corresponds to a normalized index that represents the probability of occurrence of an amount 
of precipitation, in comparison with the climatological normal of precipitation obtained over a long period of time for the specific geographic location. Negative (positive) values of SPI indicate deficit (excess) of precipitation over that location. Intensity and duration of droughts can be related, respectively, with the magnitude of the negative values of SPI and with the period of time with SPI lower than a certain threshold.

However the SPI only depends on precipitation, which has been pointed as a disadvantage. In order to incorporate the influence of temperature as well and thus incorporating evapotranspiration data, the Standardized Precipitation and Evapotranspiration Index (SPEI), has been also recently proposed (Vicente-Serrano et al., 2010). SPEI is also a normalized index with a multi-scalar characteristic, and represents the probability of incidence of a certain amount of evapotranspiration, in comparison with the climatological normal. SPEI has been used in several studies that analyzed the influence of droughts on vegetation dynamics over different biomes (Vicente Serrano et al., 2013; Gouveia et al., 2016) including objective comparisons between SPEI and SPI for the Iberian Peninsula (Vicente-Serrano et al., 2014).

The precipitation and evapotranspiration, obtained from the gridded values from the CRU TS3.21 database were used to compute the above mentioned drought indicators, which have been widely used by the authors (e.g. Russo et al., 2015; Gouveia et al., 2016). The fitting was accomplished through the application of a log-logistic distribution function (Vicente-Serrano et al., 2010). Following the approach of Vicente-Serrano et al. (2014) for assessing the increased severity of dryness over Iberia with good results, the difference between SPEI and SPI for the time scales of 12 months in December was used in this work. They observed a negative trend of this difference over Iberia, meaning that drought severity increased distinctively over the Peninsula according to both indices. In other words, although both SPI and SPEI present negative trends over Iberia, the SPEI shows a greater decrease, which includes the effect of evapotranspiration. Thus they associated the negative trend of SPEI-SPI with the increase on water demand by vegetation associated mainly to an increase of evapotranspiration.

\subsection{Corine land-cover}

With the aim of relating the land cover changes with degradation patterns over Iberia, the Corine Land Cover (CLC) map was used, available on a 250 $\mathrm{m}$ spatial resolution for Europe (http://land.copernicus.eu/pan-european/ corine-land-cover/) for the years of 1990, 2000 and 2006. Although available, the corresponding 2012 map was discarded due to several gaps and problems detected. The Corine Land Cover (CLC) classification is a database for environmental assessment and provides an inventory of biophysical surface, with 44 classes of land cover. The thematic maps were resampling to the resolution of the NDVI datasets $(8 \mathrm{~m} \times 8 \mathrm{~km})$, using the majority rule. The land cover changes within the periods 2000-1990 and 2006-2000 were then computed and, for sake 
of simplicity, the 44 classes were aggregated into 11 new land cover types (Table 1) and the percentage of each new aggregated class for the 3 land cover classifications is present in Table 2 .

Table 1. Original Corine Land Cover and new aggregated classes.

\begin{tabular}{|c|c|}
\hline Original CLC classes & Aggregated classes \\
\hline Non-irrigated arable land & 1 \\
\hline Permanently irrigated land & 2 \\
\hline Rice fields & 3 \\
\hline Vineyards & \multirow{3}{*}{4} \\
\hline Fruit trees and berry plantations & \\
\hline Olive groves & \\
\hline Pastures & 5 \\
\hline Annual crops associated with permanent crops & \multirow{4}{*}{6} \\
\hline Complex cultivation patterns & \\
\hline Land occupied by agriculture with natural vegetation & \\
\hline Agro-forestry areas & \\
\hline Broad-leaved forest & \multirow{3}{*}{7} \\
\hline Coniferous forest & \\
\hline Mixed forest & \\
\hline Natural grasslands & \multirow[b]{2}{*}{8} \\
\hline Moors and heathland & \\
\hline Sclerophyllous vegetation & 9 \\
\hline Transitional woodland-shrub & 10 \\
\hline Beaches, dunes, sands & \multirow{5}{*}{11} \\
\hline Bare rocks & \\
\hline Sparsely vegetated areas & \\
\hline Burnt areas & \\
\hline Glaciers and perpetual snow & \\
\hline
\end{tabular}

Table 2. Area occupied by different land cover types, as a percentage of total area, obtained by CLC 1990, 2000 and 2006.

\begin{tabular}{|c|c|c|c|c|c|c|c|c|c|c|c|c|}
\hline & \multicolumn{10}{|c|}{ Aggregated land cover classes } \\
\hline & 1 & 2 & 3 & 4 & 5 & 6 & 7 & 8 & 9 & 10 & 11 & Others \\
\hline CLC 1990 & 26.8 & 3.1 & 0.2 & 7.0 & 0.9 & 17.4 & 20.3 & 6.4 & 9.2 & 6.3 & 1.7 & 0.6 \\
\hline CLC 2000 & 25.9 & 3.6 & 0.3 & 7.3 & 0.9 & 17.8 & 20.1 & 6.1 & 8.6 & 6.8 & 1.8 & 0.8 \\
\hline CLC 2006 & 25.2 & 3.6 & 0.3 & 7.6 & 0.9 & 18.3 & 18.4 & 6.0 & 8.2 & 8.9 & 1.8 & 0.9 \\
\hline
\end{tabular}

\subsection{Assessment of land degradation and statistical tests}

The land degradation assessment was based on the trends of residual of the standardized NDVI (Archer, 2004; Evans and Geerken, 2004) for the period 19822012. Annual accumulated precipitation was standardized for a slightly longer period 
(1980-2012), since the precipitation on previous years will be also used in the proposed methodology. The dependence of NDVI on current and previous years' precipitation was assessed by means of the correlations for each NDVI pixel $(\mathrm{p}=0.05)$. It should be noted that each gridded value of precipitation was correlated with the different $n$ pixels of NDVI within a certain cell, obtaining $\mathrm{n}$ correlation values within each cell. In order to assess the long-term decline of vegetation that was not influenced by rainfall, a multiple linear regression (MLR) was performed, removing the long-term influence of precipitation on vegetation. The MLR combined the precipitation for the contemporaneous year (year $i$, lag0), for the previous year (year $i-1$, lag1) and for two years before (year $i-2, \operatorname{lag} 2$ ) as the predictors, i.e. considering Equation 2.

$$
N D V I_{s i m}=a \cdot \operatorname{Prec}_{i}+b \cdot \operatorname{Prec}_{i-1}+c \cdot \operatorname{Prec}_{i-2}+d
$$

Taking into account that these three predictors are in fact annually lagged versions of the same time series, the predictors were tested for possible autocorrelation for lags $0,1,2$, and the results revealed that they do not present autocorrelation. The residuals of NDVI (NDVIr) were computed as the difference between the standardized observed NDVI and the simulated NDVI. The significant trends in the time series of the residuals of NDVI were then assessed $(\mathrm{p}=0.05)$. The reliability of the trend test may be affected by the existence of autocorrelation or outliers in the time series (Hamed and Ramachandra, 1997; Lanzante, 1996). The time series of residuals were tested for autocorrelation in order to choose the appropriate trend test. If there was autocorrelation at lag 1 and lag 2, the modified Mann Kendall (Hamed and Ramachandra, 1997) test was used, otherwise the Spearman Rho test was chosen, since it is not much affected by outliers (Lanzante, 1996). The slope of the significant trends was then computed using the Theil Sen method (Theil, 1950; Sen, 1968).

The correspondence of degraded areas with the main land cover changes observed within the considered period was also performed. The land cover changes within the above mentioned periods, namely CLC 2000-1990 and CLC 2006-2000, were also considered.

\subsection{Assessment of land degradation and dryness}

The Iberian Peninsula has been hit by severe and frequent drought events in the last 3 decades (Trigo et al., 2013). Vicente-Serrano et al. (2014) have pointed an increase on drought severity and dryness over the last 6 decades, mainly related to an increase on water demand by vegetation associated mainly to an increase of evapotranspiration. They concluded that the difference between SPEI and SPI (i.e. SPEI-SPI) can be used as a suitable $t$ indicator for this type of analysis.

With the aim of characterizing the observed trends of land degradation and assess if those patterns are related with the widespread tendency of dryness, the residuals of NDVI were then correlated with the difference between SPEI and SPI for the time scale of 12 months in December, using two-tailed Pearson correlation coefficients with a 0.05 level of significance. 


\section{Results}

\subsection{NDVI and Precipitation evolution over Iberia}

The time evolution of the accumulated annual precipitation and NDVI averaged for the entire Peninsula is presented in Figure 1. Precipitation does not present any positive or negative evolution, however the extreme climatic dry and wet events of the years 2005 and 2010, respectively, are notorious. On the other hand, the results for the averaged NDVI (Figure 1, bottom panel) show a positive evolution over the considered period. Despite the large spatial heterogeneity that characterizes the entire Peninsula, the annual NDVI averaged over Iberia provides an overview of the dominant pattern of vegetation behavior.

Moreover, the slopes of significant trends of the accumulated annual NDVI and of precipitation were also computed for each pixel/grid point over the Iberian Peninsula for the available period (Figure 2a, b). In the case of the accumulated precipitation there are a small number of grid points with a significant decreasing trend being clustered in northern Spain. The South of Iberia, namely the region of central and southeastern Spain and a significant fraction of the Portuguese mainland, shows a slightly increase of accumulated precipitation for the considered period. It should be noted that these trends reflect the short period considered (1982-2012) and, as such, do not reflect the long-term decline of total annual precipitation observed in Iberia since the 1950s (Sousa et al., 2011; Hoerling et al., 2012). In contrast to the precipitation, the NDVI shows an increment of greenness widely spread over Iberia, with very restricted regions presenting a decrease on vegetation health, but limited to the Spanish provinces of Central, South, Northeastern Spain and near the Mediterranean coast of Spain (Figure 2a). However this generalized increment of greenness may be related with the widespread positive influence of the contemporaneous year precipitation that is also spread over the Peninsula (Figure 3a, b, left panel).
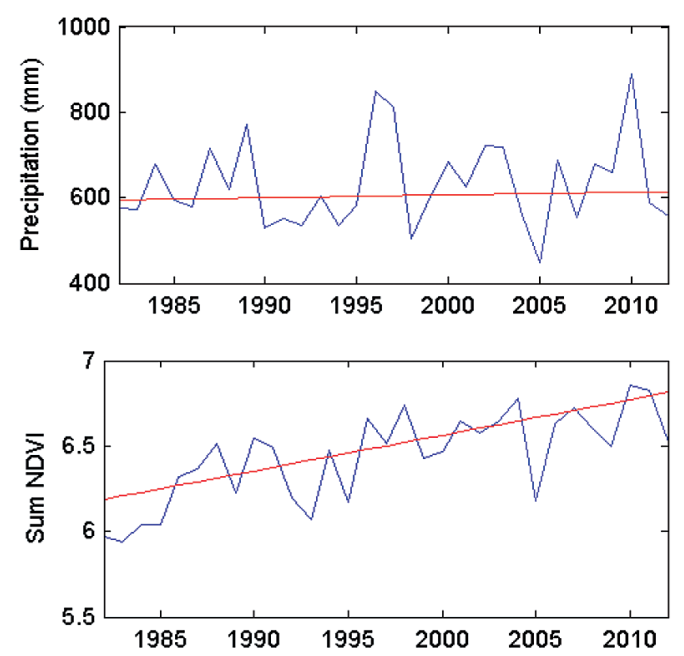

Figure 1. Temporal evolution of accumulated annual precipitation (top) and NDVI (bottom) averaged over Iberia (blue line) and corresponding linear trends (red). 
a)

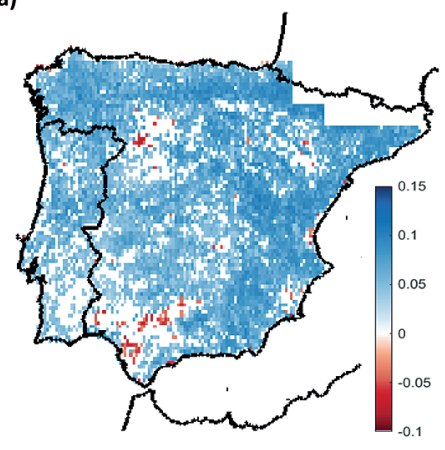

b)

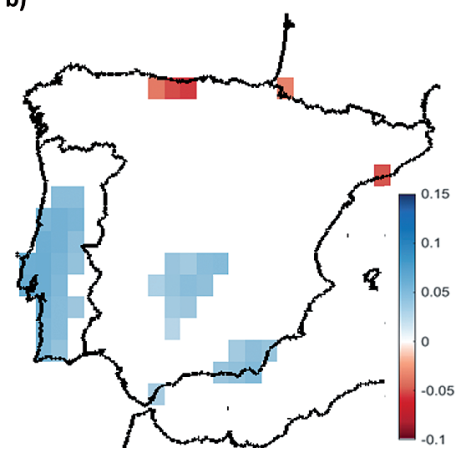

Figure 2. Spatial patterns of significant trends for the period 1982-2012 of a) annual NDVI; b) accumulated annual precipitation. Trend tests were chosen in accordance with the presence or absence of autocorrelation in the time series.

a)
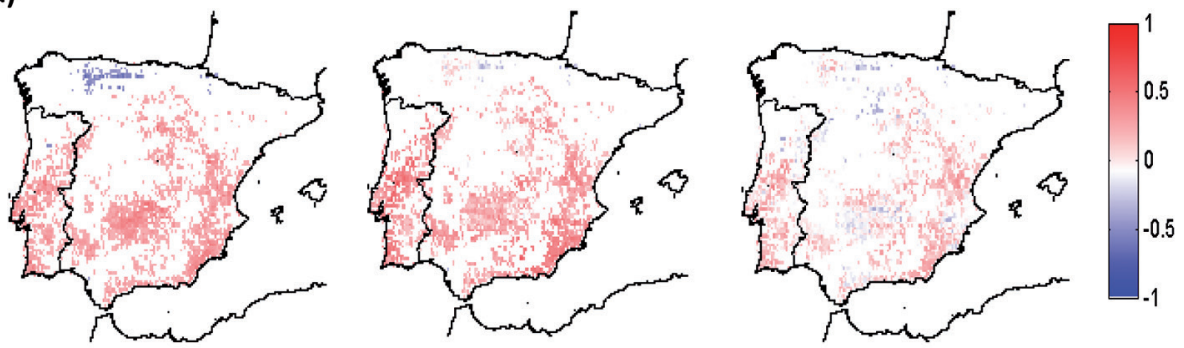

b)
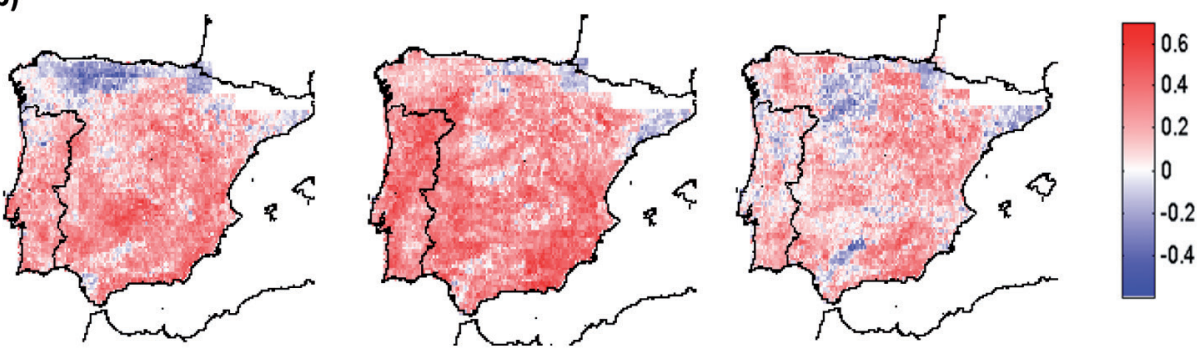

Figure 3. a) Correlation coefficients between NDVI and Precipitation for lag0, lag1, lag2; b) Coefficient estimates for the regression between standardized NDVI and standardized Precipitation for lag0, lag1 and lag2 (coefficients $a, b$ and $c$ of Equation 1).

The dependence of NDVI on precipitation was assessed by means of the correlations for each NDVI pixel. The analysis has revealed a strong influence of precipitation on vegetation over Iberia for the contemporaneous year and for some regions precipitation presents a notorious influence on vegetation (Figure 3a). The spatial patterns of coefficients estimates of the regression between standardized NDVI and standardized Precipitation for lag0, lag1 and lag2 (coefficients a, b and c of Equation 1) (Figure 3b), 
highlight also the Iberian regions where precipitation presents a more effective influence. The positive correlations between NDVI and precipitation of the previous year (Figure 3a, b middle panel) and two years prior (Figure 3a, b right panel) are still significant, stressing the memory retention nature of the driver, despite the general tendency for diminishing the absolute values of correlation. Consequently, the regression coefficients $\mathrm{b}$ and $\mathrm{c}$ still play an important role in multivariate linear regression, being positive in the majority of the pixels, although with some negative values of b close to the Pyrenees and some regions with negative values of c spread throughout the Iberia. This feature highlights again the high memory (with a lag of 1 and/or 2 years) of the precipitation influence on the vegetation of these regions. Being able to characterize the spatial and temporal framework of the influence of precipitation in the Iberian NDVI represents an important contribution. The control of precipitation on vegetation was therefore removed, and thus the obtained NDVI residuals should not reflect that driver influence.

\subsection{Evolution of NDVI residuals and Dryness over Iberia}

The spatial patterns of significant trends in residuals of NDVI (NDVIr) for the time period 1982-2012 are shown in Figure 4a. According to the results of annual NDVI trends (Figure 2a), there is a widespread improvement of land conditions over Iberia even after removing the precipitation influence, as obtained by the spatial pattern of the slope of significant positive trends of NDVIr (Figure 4a). On the other hand, the small areas presenting land degradation, as obtained by the negative NDVIr trends (Figure 4a), are coincident with the ones showing a decreasing trend of greenness (negative NDVI trend, Figure 2a). The main differences observed between the trends of NDVI (Figure 2a) and trends of NDVIr (Figure 4a) are coincident with the areas presenting significant slope trend of precipitation for the same period (Figure 2b). Moreover, those areas do not show (or show almost negligible positive) significant changes in land behavior. Another interesting feature related to the differences between trends of NDVI and trends of NDVIr is the appearance of a few points presenting land degradation, with negative NDVIr trends, in the region close to the Atlantic coast of Portugal (Figure 4a).

c)

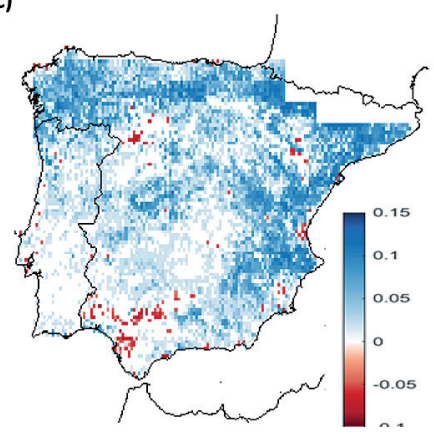

d)

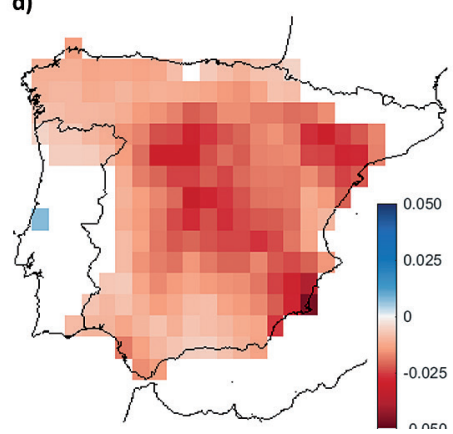

Figure 4. Spatial patterns of significant trends for the period 1982-2012 of a) residuals of NDVI and b) SPEI-SPI for the time scale of 12 months December. Trend tests were chosen in accordance with the presence or absence of autocorrelation in the time series. 
The spatial patterns of significant trends in SPEI-SPI values for the time period 19822012 are shown in Figure 4b. Trends in monthly differences of the two indices present a dominant negative trend over Iberia, with the exception of the region close to Lisbon. This negative trend indicates that SPEI presented a higher decrease than SPI, due to an increase of evapotranspiration. This negative trend presents higher slope values over central and eastern Iberia, including the Central, Southeastern and Northeastern provinces, indicating an increase of drought severity spread over Spain with higher values in those regions.

In this work we have chosen to use that difference in order to assess the relationship with land degradation and increasing dryness. The spatial patterns of significant trends (slope) of SPEI-SPI for the time scale of 12 months in December are shown in Figure 4b, always considering the time period 1982-2012. There is a spread negative trend of SPEI-SPI over Spain and North of Portugal with maximum trend around the Central and Southeastern regions. A small area located between Lisbon and Porto (Portugal) presents one hot spot of positive trends.

\subsection{Land degradation and Dryness}

The connection between land degradation and dryness was assessed by means of the determination of the correlation coefficients between the NDVIr and SPEI-SPI 12-months for the month of December (Figure 5a). The correlation is dominated by a large amount of negative values, namely in the North and Western Iberia, whereas in Central and Southern Spain regions, as well as in Portugal it is possible to identify a few small hot-spots of positive correlations.

a)

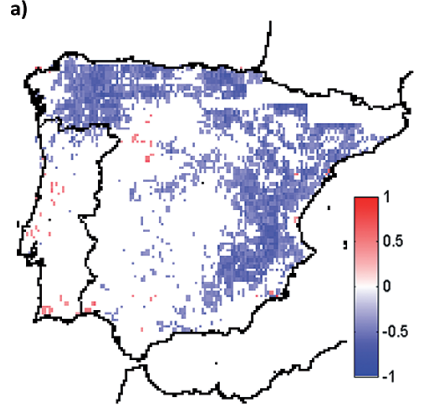

c) b)

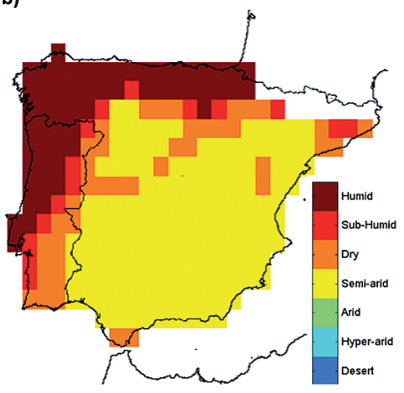

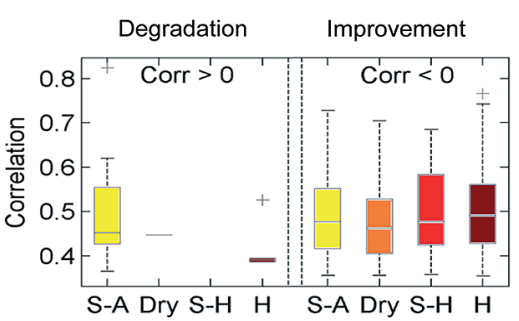

Figure 5. a) Spatial patterns of correlation coefficients between residuals of NDVIr and SPEISPI 12 on the month of December; b) Spatial distribution of aridity classes over the Iberian Peninsula; c) Boxplots of the correlation between NDVIr and SPEI-SPI for land degradation/ improvement (negative/positive NDVIr trend). 
On the other hand, and despite being in a much smaller proportion when compared with land improvement (1/30), the areas presenting land degradation (negative NDVIr trends) are almost entirely associated to pixels that do not present significant correlation of NDVIr vs. SPEI-SPI (around 80\%).

In order to analyze land degradation and improvement, as well as dryness distribution over different regions of Iberia, a characterization using the aridity index was used (Figure 5b). Although recognizing that the area affected by land degradation is around $3 \%$ of area affected by land improvement, the results show a preference of degradation by semi-arid sector with more than $80 \%$ of the area presenting land degradation, as obtained by negative trend of NDVIr (Table 3). The Dry and Sub-humid sectors present a short percentage of area with negative trend of NDVIr, whereas the humid sector shows $14 \%$ of area displaying land degradation (Table 3). On the other hand land improvement is present in all aridity sectors, with around a half of area belonging to semi-arid sector and a quarter to humid zone (Table 3).

Table 3. Percentage area of NDVI residuals with opposite trends occurring in different aridity classes.

\begin{tabular}{|c|c|c|c|c|c|}
\hline Land Condition & Semi-Arid & Dry & Sub-Humid & Humid & Total \\
\hline Degradation & 82.3 & 3.2 & 0.5 & 14.0 & 100.0 \\
\hline Improvement & 51.7 & 15.1 & 5.7 & 27.5 & 100.0 \\
\hline
\end{tabular}

An analysis of the correlation between NDVIr and SPEI-SPI 12-months for land degradation/improvement over the 4 aridity zones was performed using boxplot analysis and is presented in Figure 5c. The areas presenting land improvement (positive NDVIr trends in Fig. 4a) correspond mostly to negative correlations of NDVIr vs. SPEI-SPI (47\% of the improvement area) and thus being associated with negative trends in SPEISPI (Figure 5c, Improvement panel). Moreover, the negative correlations present large interquartile dispersion with a median value around 0.50 , with the higher correlation values corresponding to the humid and semi-arid sectors. However only few positive correlations values of NDVIr vs. SPEI-SPI were observed within the land improvement sector, corresponding only to $1 \%$ of that sector (Figure not shown), emphasizing the low control of decreasing dryness in land improvement.

Although representing a short percentage of the land degradation sector, there are still $17 \%$ of the degraded region that presents positive correlation values of NDVIr vs. SPEI-SPI, and thus experiencing an increased dryness (decrease of SPEI-SPI values). Although we can involve only about $1 / 5$ of pixels presenting land degradation with increased dryness, our results highlighted that almost all of these pixels are located inside the semi-arid sector (Figure 5c, Degradation panel). It should be noted that the boxplot regarding negative correlations NDVIr vs. SPEI-SPI was not presented, as there are only two pixels with significant correlations.

\subsection{Land degradation and land cover change}

The land cover changes observed in the considered period over Iberia were assessed by means of the changes observed on the Corine Land Cover classifications (Figure 6a) 
aggregated for the new 11 classes presented in Table 1. Consequently the changes were analyzed separately for two periods, i.e., 1990-2000 (CLC2000-CLC1990, Figure 6b) and 2000-2006 (CLC2006-CLC2000, Figure 6c). There are several factors responsible for the detected changes observed between the three considered years. Among these, the frequent occurrence of wildfires, namely those reported during the severe fire seasons of 1991, 1998, 2003 and 2005 (Garcia-Herrera et al., 2007; Gouveia et al., 2009) in Portugal (Figure 6b, green pixels). Another factor regards the arising of a large artificial lake resulting from the construction of the Alqueva's dam in the South of Portugal (Figure 6c). The enlargement of several urban perimeters, such as Lisbon, Oporto, Madrid, Zaragoza, among others (Figure 6b) and the introduction of irrigated crops in several regions of Spain (Figure 6b and $6 \mathrm{c}$, yellow pixels) were also very noticeable.
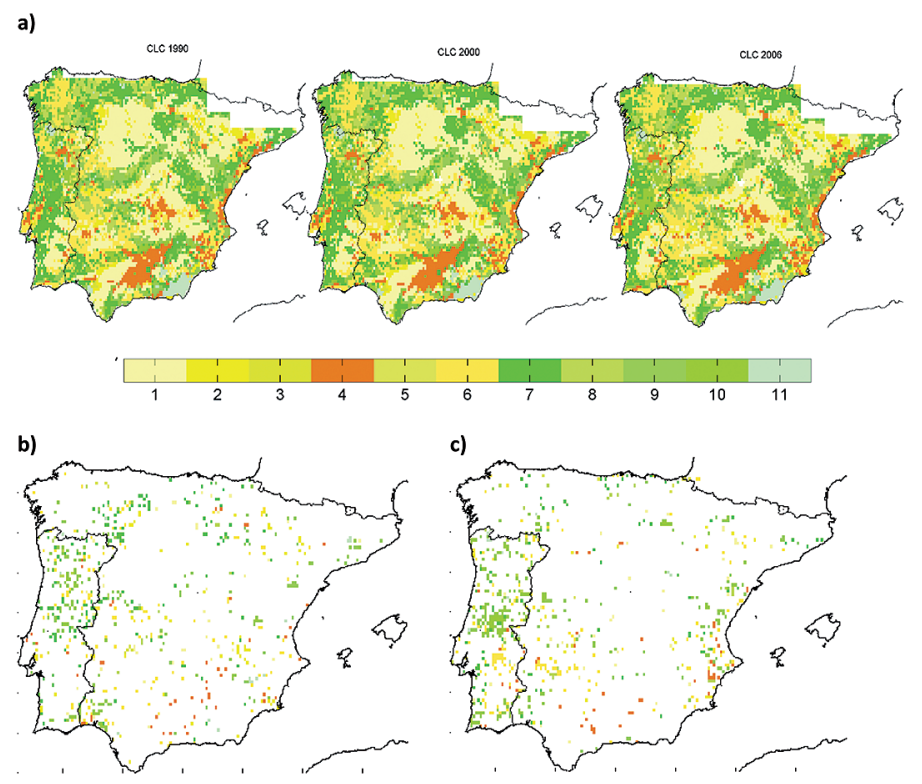

d)

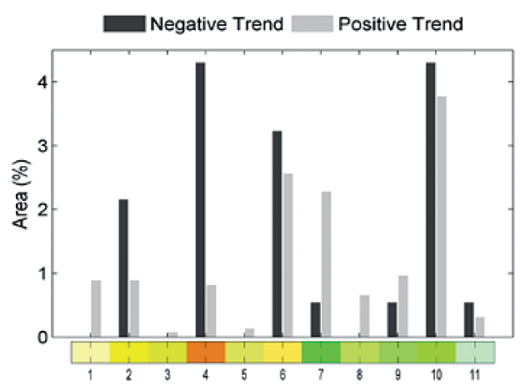

Figure 6. a) Land cover map over Iberia, as obtained by Corine Land Cover classification for 1990, 2000 and 2006; Land cover changes using Corine Land Cover classification for the periods between b) 2000-1990 and c) 2006-2000; d) Histogram of the percentage of the area corresponding to pixels presenting land degradation/improvement (negative/positive NDVIr trend) for the complete period (1990-2006). The codes in $x$-axis are shown in Table 1. 
With the aim of analyzing the relationship between land degradation/improvement with land cover changes the percentage of area with negative residuals of NDVI that correspond to changes in land cover type was computed for each 'new aggregated' land cover type of each period (Figure 6c). The artificial areas (urban and build up areas) were excluded of the analysis and the statistics were computed by summing the land cover changes for the two periods considered (CLC2000-CLC1990 and CLC2006CLC2000), taking into account that the pixels that suffered changes twice are less than $1 \%$. Land cover changes occurred only in approximately $16 \%$ of the area presenting land degradation (Figure 6d, dark grey bars), being the new land cover types associated with transitional woodland-shrub (more than $4 \%$ of the land degraded pixels), permanent crops (more than 4\%), annual crops (more than 3\%) and permanently irrigated land (almost 2\%). In the case of land improvement (Figure 6d, light grey bars), the land cover changes occurred for a shorter percentage of the area affected (around 14\%), being the most affected land cover type the transitional woodland-shrub (almost $4 \%$ of the pixels presenting land improvement), annual crops (more than 2\%) and forest (more than 2\%). It should be stressed that the land cover type of forest presents much more land improvement when compared with land degradation and the non-irrigated arable land and natural grassland do not evidence land degradation.

\section{Discussion}

Despite the increasing number of published studies devoted to land degradation, the ultimate mechanisms responsible for this phenomenon are still subject of a strong debate. This is especially true in semiarid regions, where vegetation is particularly well adapted to dry conditions and presents high resilience to drought events (Vicente-Serrano et al., 2013). Likewise, severe and frequent drought events have been pointed as the cause of land degradation in certain areas of Africa (Nicholson et al., 1998). However in recent years these regions have experienced an increase in productivity related with an increase of rainfall (Prince et al., 2007). In these regions the vegetation behavior is very complex and it becomes difficult to disentangle the effect of droughts on land degradation from other natural factors or human activities (Vicente Serrano et al., 2015). Results from previous studies (Hill et al., 2008; del Barrio et al., 2010) do not support the idea of reduced biological biodiversity and widespread desertification in Mediterranean basin, including some well-established desertification status achieved by southern and eastern parts of the Iberian Peninsula (Brandt and Thornes, 1996).

In this work we used NDVI GIMMS dataset from 1982 to 2012 that corresponds to the longest satellite dataset available, in order to assess land degradation over Iberia. To the best of our knowledge this is the first work performed with such a long period of data and considering the entire Peninsula, despite the $8 \times 8 \mathrm{~km}$ spatial resolution. Nevertheless, it is important to emphasize that this dataset has been used successfully to characterize vegetation dynamics, drought and land degradation at regional (Gouveia et al., 2016) and global (Vicente-Serrano et al., 2015) scales. Our results have stressed the widespread increment of greenness over Iberia that could be associated with positive influence of annual precipitation for the contemporaneous period. Our results are partly in agreement 
with the ones obtained using the fraction of vegetation cover in the computation of RUE by del Barrio and co-authors (2010) for the shorter period of 1989-2000, and by Hill and co-authors (2008) for 1989-2004.

Furthermore, and removing the influence of annual precipitation of the last 3 years, we also observed a generalized improvement of land conditions over Iberia in the last 3 decades, as obtained by spatial pattern of the significant positive trends of NDVI residuals obtained after accounting for the impact of precipitation in NDVI. Similar positive trends in greenness were also obtained for several distinct semi-arid regions around the Globe (Vicente-Serrano et al., 2015). On a more local/regional scale it is possible to say that some very limited regions presenting land degradation, mostly located in Central and Southern provinces of Spain with some other hot spots of degradation in the Northeastern sector, as well as close to the Mediterranean coast of Spain and to the Atlantic coast of Portugal.

The relationship between land degradation and increased dryness was implemented using the difference between SPEI and SPI. Our first results show that the area affected by land degradation stands for approximately $3 \%$ of the area affected by land improvement. This feature is in good agreement with previous findings (Bai et al., 2008, Hill et al., 2008; del Barrio et al., 2010, Vicente-Serrano et al., 2015). These results for the trends in SPEI-SPI are in good agreement with the ones of Vicente-Serrano et al. (2014) obtained for a longer period lasting 6 decades, and using data from the Portuguese and Spanish Meteorological services. Vicente-Serrano et al. (2014) have associated the negative SPEISPI trends with an increase of dryness caused by an increment of evapotranspiration.

However, both changes in land conditions seem to be associated to a generalized decrease of SPEI-SPI, highlighting the role played by the generalized greater water demand resulted from the increase in evapotranspiration in these regions (VicenteSerrano et al., 2014). Nevertheless areas showing land improvement are widely distributed over several aridity classes, whereas the around $20 \%$ of the areas exhibiting land degradation are associated with an increase of dryness and located almost in totality over semi-arid region. However the humid region also presents a considerable amount of pixels showing land degradation. Other authors have also associated the negative trends of greenness with lower aridity, while the areas showing increase trend are located to the most arid regions (Vicente-Serrano et al., 2015). The percentage of land degradation that presents a connection with increased dryness over semi-arid regions seems to suggest a climatic control over land conditions; however the short percentage of degraded pixels that exhibit that control may also suggest that other factors should be considered.

Actually the highly managed character of land in the Mediterranean basin is also observed in Iberian Peninsula. Several factors have contributed to the land cover changes observed in Iberia in the considered period. However our results showed that land cover changes occurred for less than $20 \%$ of the degraded area, being the new land covers' types mainly associated with transitional woodland-shrub, permanent and annual crops and permanently irrigated land. In the case of land improvement the most affected land cover type was transitional woodland-shrub, annual crops and forest. The land cover types showing land degradation and improvement (crops, grassland and transitional 
woodland-shrub) are those identified by other authors as the land cover involved in land state changes. The exception is related with forest, but this change may be associated with the extreme fire seasons of 2003 and 2005 that have destroyed a large area of forest that have been recovering naturally or induce by human action. Despite the short percentage of degraded pixels that experienced land cover changes, which seems to indicate that those changes do not represent also the main reason for land degradation in the considered period, the analysis of the affected land cover reveals to be important. This feature suggests that land degradation occurs within the lifetime of some land cover types and consequently supports the new conceptual approach proposed by Bestelmeyer et al. (2015) wherein desertification consists of land states shifting within concrete land uses (e.g. rangeland, cropland). The above mentioned authors contrast the case of state changes with regime shifts, being the former readily reversed, while the later are involving persistent changes on vegetation or soil properties. Socioeconomic factor, such as migrations and agricultural prices, can induce land use fluctuations. Climate variability, such as droughts or increased rainfall, may also reinforce or attenuated these fluctuations. However the low resilience of soils may limit the vegetation recovery and a strong socioeconomic pressure, such as the increasing grazing or persistent loss of vegetation may result in land degradation. Consequently, to disentangle between equilibrium, non-equilibrium and regime-shifts states will constitute a power tool for management and policy responses (Bestelmeyer et al., 2015).

The increase in productivity has been related with an increase of wetness observed in the Northwestern area, whereas land degradation was related with an increase of aridity that was observed over the Mediterranean zone of Iberia (del Barrio et al., 2010). Hill and co-authors (2008) found several different patches of degradation, mainly caused by the wildfires that occurred in the end of the period considered in their study (19892004), that were coincident with the severe fires season of 2003, namely in Portugal. On the other hand, they attributed the widespread improvement in land conditions with the abandonment of rural areas (Hill et al., 2008), which are primarily characterized by an increased vegetation cover and density. The Mediterranean region has a recognized long history of land management and, in the last few decades, it is noticeable the decrease of economic activities in rural areas, the conversion of croplands to pastures, the increased grazing and the reduction of wood extraction (Reale and Dirmeyer, 2000). While the increase of shrub cover and the consequent increase of fire activity and the loss of soil fertility could be associated with the decline in greenness, the crop intensification and land cover changes could be associated with the increment of greenness (Evans and Geerken, 2004; Vicente-Serrano et al., 2015) and this feature was observed in Central Spanish Pyrenees (Vincente-Serrano et al., 2005), north-western Spain and central Spain (Crecente et al., 2002; Romero-Calcerrada and Perry, 2004), and in Portugal (Moreira et al., 2001). The increased greenness could also be related with hydrological cycles and aquifers (Hill et al., 2008). In fact, the decline in productivity observed during the last decades of the XX century in the semi-arid region of Alentejo in the South of Portugal, was inverted due to the construction, in the beginning of the XXI century, of the biggest artificial lake in Iberian Peninsula, the Alqueva. The Alqueva dam is providing water to agricultural practices and, at the same time, has contributed to an increase in the humidity 
of the region. Consequently the region does not present any signal of degradation in the period analyzed in the work. A similar feature was observed in southern Spain in the end of XX century, with the construction of Serena dam. The water availability made possible by dams of large dimension together with an increased number of small dams in Spain and Portugal, have incremented the permanently irrigated crops over the Peninsula. Moreover the land cover types changed during the period of time considered in this work are in good agreement with land degradation and improvement: the transitional woodland-shrub and the annual and permanent crops. As mentioned before these land covers are mainly related with the agricultural practices and rural exodus.

\section{Conclusions}

The methodology used to remove the effect of precipitation on vegetation activity proposed in this work has enabled the mapping of land conditions over Iberia Peninsula. In the Iberian Peninsula the effect of precipitation on vegetation has a long memory effect, achieving in some regions a lag of 2 years. The novelty of our approach is related with the ability to remove the 3 -years signal of precipitation in greenness. This work has demonstrated also the important role of remote sensing datasets for a continuous mapping of land degradation. The length of the considered period (1982 through 2012) represents strength, as well as the use of globally available archived data of both remote sensing data of GIMMS-NDVI and climate datasets.

The application of this approach to the assessment of land degradation over Iberian Peninsula led to the following main achievements:

- widespread increment of greenness over Iberia that is likely associated with positive influence of annual precipitation for the contemporaneous period;

- detection of few hot spots of greenness decline in central and southern sectors of Iberia;

- generalized improvement of land conditions over Iberia with few hot spots of land degradation located mainly in central and southern sectors of Iberia, as well as in east Mediterranean and west Atlantic coasts;

- $\quad$ land improvement is observed throughout most of Iberia, despite the increase tendency for dryness for all aridity classes, being only associated with a trend for wetness in the northeastern humid sector;

- the association of land degradation with increased dryness is observed only for a small percentage of the degraded pixels, although almost the totality over semi-arid region;

- $\quad$ changes in dryness may not explain several of the observed changes in land conditions;

- land degradation/improvement affected mainly transitional woodland-shrub, permanent and annual crops and permanently irrigated land covers;

- $\quad$ the percentage of area experiencing land improvement is greater than the area showing degradation for forests and non-irrigated arable land; 
- the percentage of area experiencing land degradation exceeds the area presenting improvement for forests and arable irrigated and annual crops;

- $\quad$ our results are compatible with the new conceptual approach of land state changes;

- $\quad$ the combined effect of climate variability and land cover changes induced by human activities seems to have the ability of explaining a larger number of land changes.

Nevertheless we are aware that further work is necessary to confirm some of the results obtained in particular a better interpretation of the observed changes will be obtained using higher resolution NDVI and precipitation datasets. Furthermore, the map of land degradation could be a reference extremely useful for helping decision makers in defining priorities and mitigation strategies.

\section{Acknowledgements}

This work was partially supported by national funds through FCT (Fundação para a Ciência e a Tecnologia, Portugal) under project QSECA (PTDC/AAGGLO/ 4155/2012). A. Russo was supported by FCT through grant SFRH/BPD/99757/2014.

\section{References}

Anyamba, A., Tucker, C.J. 2005. Analysis of Sahelian vegetation dynamics using NOAA-AVHRR NDVI data from 1981-2003. Journal of Arid Environments 63, 596-614.

Archer, E.R.M. 2004. Beyond the "climate vs. grazing" impasse: Using remote sensing to investigate the effects of grazing system choice on vegetation cover in the eastern Karoo. Journal of Arid Environments 57, 381-408.

Arribas, A., Gallardo, C., Gaertner, M.A., Castro, M. 2003. Sensitivity of the Iberian Peninsula climate to a land degradation. Climate Dynamics 20, 477-489. Doi: 10.1007/s00382-0020285-1.

Bai, Z.G., Dent, D.L., Olsson, L., Schaepman, M.E. 2008. Proxy global assessment of land degradation. Soil Use and Management 24, 223-234.

Bastos, A., Gouveia, C.M., Trigo, R.M., Running, S.W. 2014. Analysing the spatio-temporal impacts of the 2003 and 2010 extreme heat waves on plant productivity in Europe. Biogeosciences 11, 3421-3435. Doi: 10.5194/bg-11-3421-2014.

Bastos, A., Janssens, I.A., Gouveia, C.M., Trigo, R.M. Ciais, P., Chevallier, F., Peñuelas, J., Rödenbeck, C., Piao, S., Friedlingstein, P., Running, S.W. 2016. European CO2 sink influenced by NAO and East-Atlantic Pattern coupling, Nature Communications. Doi: 10.1038/NCOMMS10315.

Bestelmeyer, B.T., Okin, G.S., Duniway, M.C., Archer, S.R., Sayre, N.F., Williamson, J.C. and Herrick, J.E. 2015. Desertification, land use, and the transformation of global drylands. Frontiers in Ecology and Environment 13 (1), 28-36. Doi: 10.1890/140162.

Brandt, C., Thornes. J. (eds.) 1996. Mediterranean Desertification and Land Use. John Wiley, Chichester, 554 pp.

Buermann, W., Anderson, B., Tucker, C.J., Dickinson, R.E., Lucht, W., Potter, C.S., Myneni, R.B. 2003. Interannual covariability in NorthernHemisphere air temperatures and greenness 
associated with El Niño-southern oscillation and the Arctic Oscillation. Journal of Geophysical Research 108, 4396. Doi: 10.1029/2002JD002.

Crecente, R., Álvarez, C., Fra, U. 2002. Economic, social and environmental impact of land consolidation in Galicia. Land Use Policy 19, 135-147.

Dardel, C., Kergoat, L., Hiernaux, P., Grippa, M., Mougin, E., Ciais, P., Nguyen, C.C. 2014. Rainuse-efficiency: What it tells us about the conflicting Sahel greening and Sahelian paradox. Remote Sensing 6, 3446-3474.

De Jong, R., de Bruin, S., de Wit, A., Schaepman, M.E., Dent, D.L. 2011. Analysis of monotonic greening and browning trends from global NDVI time-series. Remote Sensing and Environment 115, 692-702.

De Wrachien, D., Ragab, R., Giordano, A. 2006. Climate change, land degradation, and desertification in the Mediterranean environment. In W.G. Kepner, J.L. Rubio, D.A. Mouat, F. Pedrazzini (eds.), Desertification in the Mediterranean Region. A Security Issue, NATO Security Through Science Series, Springer, Volume 3, pp. 353-371.

Del Barrio, G., Puigdefabregas, J., Sanjuan, M.E., Stellmes, M., Ruiz, A. 2010. Assessment and monitoring of land condition in the Iberian Peninsula, 1989-2000. Remote Sensing of Environment 114, 1817-1832.

Eklundh, L., Olsson, L. 2003. Vegetation index trends for the African Sahel 1982-1999. Geophysical Research Letters 30. Doi: 10.1029/2002GL016772.

Evans, J., Geeren, R. 2004. Discrimination between climate and human-induced dryland degradation. Journal of Arid Environments 57, 535-554.

Fensholt, R., Sandholt, I., Rasmussen, M.S. 2004. Evaluation of MODIS LAI, fAPAR and the relation between fAPAR and NDVI in a semi-arid environment using in situ measurements. Remote Sensing of Environment 91, 490-507.

Fensholt, R., Rasmussen, K. 2011. Analysis of trends in the Sahelian "rain-use efficiency" using GIMMS NDVI, RFE and GPCP rainfall data. Remote Sensing of Environment 115, 438-451.

Fensholt, R., Rasmussen, K., Kaspersen, P., Huber, S., Horion, S., Swinnen, E. 2013. Assessing land degradation/recovery in the African Sahel from long-term earth observation based primary productivity and precipitation relationships. Remote Sensing 5, 664-686.

García-Herrera, R., Paredes, D., Trigo, R.M., Trigo, I.F., Hernández, H., Barriopedro, D., Mendes, M.T. 2007. The outstanding 2004-2005 drought in the Iberian Peninsula: associated atmospheric circulation. Journal of Hydrometeorology 8, 483-498.

Gouveia, C., Trigo, R.M., DaCamara, C.C., Libonati, R., Pereira, J.M.C. 2008. The North Atlantic Oscillation and European vegetation dynamics. International Journal of Climatology 28, 1835-1847.

Gouveia, C., Trigo, R.M., DaCamara, C.C. 2009. Drought and vegetation stress monitoring in Portugal using satellite data. Natural Hazards and Earth System Sciences 9, 185-195. Doi: 10.5194/nhess-9-185-2009.

Gouveia, C.M., Bastos, A., Trigo, R.M., DaCamara, C.C. 2012. Drought impacts on vegetation in the pre- and post-fire events over Iberian Peninsula. Natural Hazards and Earth System Sciences 12, 3123-3137. Doi: 10.5194/nhess-12-3123-2012.

Gouveia, C.M., Trigo, R.M., Beguería, S., Vicente-Serrano, S.M. 2016. Drought impacts on vegetation activity in the Mediterranean region: an assessment using remote sensing data and multi-scale drought indicators. Global and Planetary Change (submitted).

Hamed, K.H., Ramachandra, A. 1997. A modified Mann-Kendall trend test for autocorrelated data. Journal of Hydrology 204, 182-196.

Hargreaves, G.H., Samani, Z.A. 1985. Reference crop evapotranspiration from temperature. Applied Engineering in Agriculture 1, 96-99. Doi: 10.13031/2013.26773. 
Harris, I., Jones, P.D., Osborn, T.J., Lister, D.H. 2014. Updated high-resolution grids of monthly climatic observations - the CRU TS3.10 Dataset. International Journal of Climatology 34, 623-642. Doi: 10.1002/joc.3711.

Hein, L., de Ridder, N. 2006. Desertification in the Sahel: A reinterpretation. Global Change Biology 12, 751-758.

Herrmann, S.M., Anyamba, A., Tucker, C.J. 2005. Recent trends in vegetation dynamics in the African Sahel and their relationship to climate. Global Environmental Change 15 (4), 394 404.

Hickler, T., Eklundh, L., Seaquist, J.W., Smith, B., Ardö, J., Olsson, L., Sykes, M.T., Sjöström, M. 2005. Precipitation controls Sahel greening trend. Geophysical Research Letters 32. Doi: 10.1029/2005GL024370.

Higginbottom, T.P., Symeonakis, E. 2014. Assessing land degradation and desertification using vegetation index data: Current frameworks and future directions. Remote Sensing 6, 95529575. Doi: 10.3390/rs6109552.

Hill, J., Stellmes, M., Udelhoven, T., Röder, A., Sommer, S. 2008. Mediterranean desertification and land degradation: mapping related land use change syndromes based on satellite observations. Global and Planetary Change 64 (3), 146-157.

Hoerling, M., Eischeid, J., Perlwitz, J., Quan, X., Zhang, T., Pegion, P., 2012. On the Increased Frequency of Mediterranean Drought. Journal of Climatology 25, 2146-2161.

Holm, A.M.S., Cridland, W., Roderick, M.L. 2003. The use of time-integrated NOAA NDVI data and rainfall to assess landscape degradation in the arid shrubland of Western Australia. Remote Sensing of Environment 85, 145-158.

Holben, B.N. 1986. Characteristics of maximum-value composite images from temporal AVHRR data, International Journal of Remote Sensing 7, 1417-1434.

Huber, S., Fensholt, R., Rasmussen, K. 2011. Water availability as the driver of vegetation dynamics in the African Sahel from 1982 to 2007. Global and Planetary Change 76, 186-195.

Hulme, M. 2001. Climatic perspectives on Sahelian desiccation: 1973-1998. Global Environmental Change 11, 19-29.

IPCC 2012. Managing the Risks of Extreme Events and Disasters to Advance Climate Change Adaptation. A Special Report of Working Groups I and II of the Intergovernmental Panel on Climate Change. C.B. Field, V. Barros, T.F. Stocker, D. Qin, D.J. Dokken, K.L. Ebi, M.D. Mastrandrea, K.J. Mach, G.K. Plattner, S.K. Allen, M. Tignor, P.M. Midgley (eds.). Cambridge University Press, Cambridge, UK, and New York, NY, USA, 582 pp.

Lanzante, J.R. 1996. Resistant, robust and non-parametric techniques for the analysis of climate data: theory and examples, including applications to historical radiosonde station data. International Journal of Climatology 16, 1197-1226.

Le Houerou, H.N. 1984. Rain use efficiency: A unifying concept in arid-land ecology. Journal of Arid Environments 7, 213-247.

McKee, T.B., Doesken, N.J., Kleist, J. 1993. The relationship of drought frequency and duration to time scales. Eighth Conference on Applied Climatology, 17-22 January 1993, Anaheim, California.

Mitchell, T.D., Jones, P.D. 2005. An improved method of constructing a database of monthly climate observations and associated high-resolution grids. International Journal of Climatology 25, 693-712. Doi: 10.1002/joc.1181.

Moreira, F., Rego, F.C., Ferreira, P. 2001. Temporal (1958-1995) pattern of change in a cultural land-scape of northwestern Portugal: implications for fire occurrence. Landscape Ecology $16,557-567$.

Myneni, R.B., Keeling, C.D., Tucker, C.J., Asrar, G., Nemani, R.R. 1997. Increase plant growth in the northern high latitudes from 1981-1991. Nature 386, 698-702. 
Nemani, R.R., Keeling, C., Hashimoto, H., Jolly, W.M., Piper, S.C., Tucker, C.J., Myneni, R.B., Running, S.W. 2003. Climate-driven increases in global terrestrial net primary production from 1982 to 1999. Science 300, 1560-1563.

Nicholson, S.E., Tucker, C.J., Ba, M.B. 1998. Desertification, drought, and surface vegetation: An example from the West African Sahel. Bulletin of the American Meteorological Society 79, 815-830.

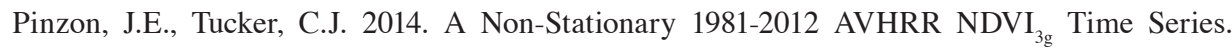
Remote Sensing 6, 6929-6960.

Phillips, L.B., Hansen, A.J., Flather, C.H. 2008. Evaluating the species energy relationship with the newest measures of ecosystem energy: NDVI versus MODIS primary production. Remote Sensing of Environment 112, 4381-4392.

Prince, S.D., de Colstoun, E.B., Kravitz, L.L. 1998. Evidence from rain-use efficiencies does not indicate extensive Sahelian desertification. Global Change Biology 4, 359-374.

Prince, S.D., Wessels, K.J., Tucker, C.J., Nicholson, S.E. 2007. Desertification in the Sahel: A reinterpretation of a reinterpretation. Global Change Biology 13, 1308-1313.

Reale, O., Dirmeyer, P. 2000. Modeling the effects of vegetation on Mediterranean climate during the Roman classical period. Part I, climate history and model sensitivity. Global and Planetary Change 25, 163-184.

Romero-Calcerrada, R., Perry, G.L.W. 2004. The role of land abandonment in landscape dynamics in the SPA 'Encinares del rio Alberche y Cofio' central Spain, 1984-1999. Landscape and Urban Planning 66 (4), 217-232.

Russo, A., Gouveia, C., Trigo, R., Liberato, M.L.R., DaCamara, C.C. 2015. The influence of circulation weather patterns at different spatial scales on drought variability in the Iberian Peninsula. Frontiers in Environmental Science 3, 42-56. Doi: org/10.3389/fenvs.2015.00001.

Safriel, U., Adeel, Z. 2005. Dryland systems. In R. Hassan, R.J. Scholes, N. Ash (eds.), Ecosystems and Human Well-Being. Volume 1, Current State and Trends, Island Press, London, UK, pp. 623-662.

Sen, P.K. 1968. Estimates of the regression coefficient based on Kendall's tau. Journal of the American Statistical Association 63, 1379-1389.

Spinoni, J., Vogt, J., Naumann, G., Carrao, H., Barbosa, P. 2015. Towards identifying areas at climatological risk of desertification using the Koppen-Geiger classification and FAO aridity index. International Journal of Climatology 35, 2210-2222.

Sousa, P., Trigo, R.M., Aizpurua, P., Nieto, R., Gimeno, L., García-Herrera, R. 2011. Trends and extremes of drought indices throughout the 20th century in the Mediterranean. Natural Hazards and Earth System Sciences 11, 33-51.

Tucker, C.J., Pinzon, J.E., Brown, M.E., Slayback, D.A., Pak, E.W., Mahoney, R., Vermotte, E.F., El Saleous, N. 2005. An extended AVHRR 8-km NDVI dataset compatible with MODIS and SPOT vegetation NDVI data. International Journal of Remote Sensing 26, 4485-4498.

Theil, H. 1950. A rank-invariant method of linear and polynomial regression analysis. Proceedings of the Royal Netherlands Academy of Sciences 53, 386-392, 521-525, 1397-1412.

Trigo, R.M., Añel, J., Barriopedro, D., García-Herrera, R., Gimeno, L., Nieto, R., Castillo, R., Allen, M.R., Massey, N. 2013. The record winter drought of 2011-12 in the Iberian Peninsula. Bulletin of the American Meteorological Society 94 (9), S41-S45.

UNCCD (United Nations Convention to Combat Desertification) 1994. Elaboration of an international convention to combat desertification in those countries experiencing serious drought and/or desertification, particularly in Africa. Paris, United Nations Convention to Combat Desertification A/AC.241/27. Available at: https://treaties.un.org/pages/ ViewDetails.aspx?src=TREATY\&mtdsg_no=XXVII-10\&chapter=27\&lang=en. 
Verón, S.R., Paruelo, J.M. 2010. Desertification alters the response of vegetation to changes in precipitation. Journal of Applied Ecology 47, 1233-1241.

Vicente-Serrano, S.M., López-Moreno, J.I., Beguería, S. 2010. A multi-scalar drought index sensitive to global warming: The standardized precipitation evapotranspiration index SPEI. Journal of Climate 23, 1696-1718. Doi: http://dx.doi.org/10.1175/2009JCLI2909.1.

Vicente-Serrano, S.M., López-Moreno, J.I., Drumond, A., Gimeno, L., Nieto, R., Morán-Tejeda, E., Lorenzo-Lacruz, J., Beguería, S., Zabalza, J. 2011. Effects of warming processes on droughts and water resources in the NW Iberian Peninsula (1930-2006). Climate Research 48, 203-212.

Vicente-Serrano, S.M., Gouveia, C., Camarero, J.J., Beguería, S., Trigo, R.M., López-Moreno, J.I., Azorín-Molina, C., Pasho, E., Lorenzo-Lacruz, J., Revuelto, J, Morán-Tejeda, E., Sanchez-Lorenzo, A. 2013. Response of vegetation to drought time-scales across global land biomes. Proceedings of the National Academy of Sciences 110, 52-57. Doi: 10.1073/ pnas. 1207068110.

Vicente-Serrano, S.M., Lopez-Moreno, J.I., Beguería, S., Lorenzo-Lacruz, J., Sánchez-Lorenzo, A., García-Ruiz, J.M., Azorín-Molina, C., Morán-Tejeda, E., Revuelto, J., Trigo, R.M., Coelho, F., Espejo, F. 2014. Evidence of increasing drought severity caused by temperature rise in southern Europe. Environmental Research Letters 9, 044001.

Vicente-Serrano, S.M., Cabello, D., Tomás-Burguera, M., Martín-Hernández, N., Beguería, S., Azorin-Molina, C., El Kenawy, A. 2015. Drought Variability and Land Degradation in Semi-arid Regions: Assessment Using Remote Sensing Data and Drought Indices (19822011). Remote Sensing 7, 4391-4423. Doi: 10.3390/rs70404391. 